\title{
Metal contents in soils irrigated with diluted treated produced water from oil
}

\author{
Danniely O. Costa ${ }^{1}$, Hudson S. M. Vale ${ }^{1}$, Rafael O. Batista ${ }^{2}$, Kaline D. Travassos ${ }^{1}$, Marcelo T. Gurgel ${ }^{1} \&$ \\ Luis C. de A. Lemos Filho \\ ${ }^{1}$ Universidade Federal Rural do Semi-Árido/Departamento de Ciências Agronômicas e Florestais. Mossoró, RN, Brasil. E-mail: danniely_oliveira@hotmail.com \\ - ORCID: 0000-0001-7966-9417; klaus_angel@hotmail.com - ORCID: 0000-0002-5391-117X; kalinedantas@yahoo.com.br - ORCID: 0000-0002-5882-0402; \\ marcelo.tavares@ufersa.edu.br - ORCID: 0000-0001-7457-0645 \\ ${ }^{2}$ Universidade Federal Rural do Semi-Árido/Departamento de Engenharia e Ciências Ambientais. Mossoró, RN, Brasil. E-mail: rafaelbatista@ufersa.edu.br \\ (Corresponding author) - ORCID: 0000-0002-3083-6808; lcalfilho@ufersa.edu.br - ORCID: 0000-0001-8527-2686
}

\begin{abstract}
The objective of this study was to evaluate changes in soil metal contents in an Ultisol cultivated with forage cactus (Nopalea cochenillifera) irrigated with diluted treated oil produced water (TOPW). The experiment was conducted in a randomized block design with five replications. The treatments consisted of $100 \%$ underground water (T1); $75 \%$ underground water plus 25\% TOPW (T2); 50\% underground water plus 50\% TOPW (T3); 25\% underground water plus 75\% TOPW (T4); and 100\% TOPW (T5). The plots consisted of 25 pots of $20 \mathrm{~L}$ in a greenhouse, in Mossoró, RN, Brazil. Soil samples from the 0-0.10 $\mathrm{m}$ and 0.10-0.20 m layers were collected at 240 days after planting, and $\mathrm{Fe}, \mathrm{Mn}, \mathrm{Cu}, \mathrm{Zn}, \mathrm{Cr}, \mathrm{Ni}, \mathrm{Cd}$, and $\mathrm{Pb}$ contents were evaluated. The use of irrigations with diluted TOPW caused no contamination of the soils cultivated with forage cactus by the evaluated metals. T2 presented the lowest metal contents. $\mathrm{Cr}$ and $\mathrm{Pb}$ contents in the soil were significantly high, indicating that the application of TOPW should not be used continuously in the same area.
\end{abstract}

Key words: industrial residue, reuse, trace elements, mobility

\section{Concentração de metais em solo irrigado com diluições de água tratada produzida do petróleo}

RESUMO: Objetivou-se com este estudo avaliar a alteração nos teores de metais em um Ultisol, cultivado com palma forrageira (Nopalea cochenillifera) e irrigado com diluições de água produzida de petróleo tratada. O experimento foi montado no delineamento em blocos casualizados, com cinco tratamentos (T1 - 100\% de água subterrânea; T2 - 75\% de água subterrânea mais 25\% de água produzida; T3 - 50\% de água subterrânea mais 50\% de água produzida; T4 - 25\% de água subterrânea mais 75\% de água produzida; e T5 - 100\% de água produzida), com cinco repetições. O trabalho foi conduzido em 25 vasos de $20 \mathrm{~L}$ dentro de casa de vegetação, em Mossoró, RN. Aos 240 dias após o plantio foram coletadas amostras do solo, nas profundidades de 0 a 0,10 m e de 0,10 a 0,20 m, para avaliação dos metais Fe, Mn, Cu, Zn, Cr, Ni, Cd e Pb. O uso de diluições da água produzida do petróleo tratada não acarretou contaminação do solo cultivado com palma forrageira em relação aos metais, sendo que no T2 houve os menores aportes de metais. Ocorreu aumento significativo de $\mathrm{Cr}$ e $\mathrm{Pb}$ no solo, indicando que a aplicação de água produzida do petróleo tratada não deve ser realizada de forma contínua em uma mesma área.

Palavras-chave: resíduo industrial, reúso, elementos traço, mobilidade 


\section{INTRODUCTION}

Many exploration and production activities, including oil industries, produce large quantities of residues and effluents. The greatest volume of effluents from oil industries is the produced water, which consists of a mixture of water from natural formation (larger part) below or inside oil and gas reservoirs, reinjected water, and chemical compounds used during the drilling, stimulation, production, and oil-water separation processes (Santos et al., 2014; Drioli et al., 2016).

A water-oil proportion of 10.5:1 is estimated for 2020 in the world, considering onshore and offshore explorations, expecting a produced water volume from oil extraction of approximately of 54 billion $\mathrm{m}^{3}$ (BP, 2017).

The possibility of reusing these produced waters for irrigation of agricultural crops is interesting for the oil industry and farmers, especially those in semiarid regions, such as the Northeast of Brazil (Sousa et al., 2016).

However, produced water should not be applied at excessive rates to the soil surface or reused without treatment, because it may present high contents of disperse oil, total dissolved solids, inorganic chemical compounds, and heavy metals (Al-Ghouti et al., 2019), requiring previous evaluations for accumulations of potentially toxic elements in the soil and plant tissues (Ferreira et al., 2015; Pica et al., 2017; Echchelh et al., 2019).

In this context, the objective of this study was to evaluate changes in soil metal contents in an Ultisol cultivated with forage cactus (Nopalea cochenillifera) irrigated with diluted treated oil produced water, in Mossoró, RN, Brazil

\section{Material ANd Methods}

The experiment was conducted from January to September 2018 in a greenhouse of the Department of Agricultural and Forest Sciences (DCAF) of the Federal Rural University of the Semi-arid Region (UFERSA, West campus), in the municipality of Mossoró, state of Rio Grande do Norte (RN), Brazil ( $5^{\circ} 12^{\prime} 11.25^{\prime \prime} \mathrm{S}, 37^{\circ} 19^{\prime} 25.77^{\prime \prime} \mathrm{W}$, and altitude of $\left.18 \mathrm{~m}\right)$. The climate of the region is BSh, according to the Köppen classification (Álvares et al., 2013).
The soil used in the experiment was classified as an Ultisol, which was collected at the UFERSA Rafael Fernandes Experimental Farm, in the district of Alagoinha, rural area of Mossoró. The soil was subjected to chemical analyses before the experiment (Table 1), at the Laboratory of Soil, Water, and Plant Analysis (LASAP-UFERSA), following the methodology described by Teixeira et al. (2017).

The produced water was obtained from an oil field in the district of Jucuri, which is in a rural area of Mossoró, $\mathrm{RN}$, Brazil. The water was stored in the experiment site and treated with AGEFLOC/DW-3753, which is a strongly cationic polyelectrolyte organic polymer used for flocculation of suspended matter in oil fields and general water.

The underground water used to dilute the treated oil produced water (TOPW) was from a tubular well of the Water and Sewer Company of Rio Grande do Norte (CAERN).

The treatments followed the recommendations for wastewater dilution in underground water proposed by Costa et al. (2018) to minimize risks of soil salinization and sodification.

The experiment was conducted in a randomized block design with five treatments and five replications. The treatments consisted of $100 \%$ underground water (T1); $75 \%$ underground water plus 25\% TOPW (T2); 50\% underground water plus 50\% TOPW (T3); $25 \%$ underground water plus $75 \%$ TOPW (T4); and 100\% TOPW (T5).

TOPW samples were collected from the five treatments every two months during the experiment, totaling four samples per treatment. The TOPW chemical analyses (Table 2) were carried out following the recommendations of the Standard Methods for the Examination of Water and Wastewater (Rice et al., 2012).

The experimental plots were represented by 25 pots of $20 \mathrm{~L}$ lined up on bricks with $0.19 \mathrm{~m}$ height, spaced $1.20 \mathrm{~m}$ between blocks and $0.50 \mathrm{~m}$ between plots of the same block. The pots were filled with approximately $1.0 \mathrm{~kg}$ of crushed stones $(9.5-19 \mathrm{~mm})$ covering the base of the pots, a polypropylene mesh over the crushed stones, and $12 \mathrm{~kg}$ of soil; 16-mm diameter holes were drilled in the bottom of each pot to drain the TOPW surplus.

Table 1. Initial chemical attributes of the soil used in the experiment

\begin{tabular}{|c|c|c|c|c|c|c|c|c|c|}
\hline Layer & nH & $\mathrm{Fe}$ & $\mathrm{Mn}$ & $\mathrm{Cu}$ & $\mathrm{Zn}$ & $\mathrm{Cr}$ & $\mathrm{Ni}$ & Cd & $\mathrm{Pb}$ \\
\hline$(m)$ & $\mathrm{pli}$ & \multicolumn{8}{|c|}{$\left(m g d m^{-3}\right)$} \\
\hline $0-0.10$ & 6.10 & 1.56 & 0.56 & 0.01 & 0.20 & 0.021 & 0 & 0 & 0.01 \\
\hline $0.10-0.20$ & 4.80 & 1.95 & 0.55 & 0.02 & 0.20 & 0.006 & 0 & 0 & 0.16 \\
\hline
\end{tabular}

Table 2. Means and standard deviations for chemical attributes of the diluted treated water produced from oil used for irrigation of soils cultivated with forage cactus, using four samples collected during the experiment period

\begin{tabular}{|c|c|c|c|c|c|c|c|c|c|c|c|c|c|c|c|}
\hline \multirow{2}{*}{ Chemical attributes } & \multicolumn{15}{|c|}{ Mean and standard deviation } \\
\hline & \multicolumn{3}{|c|}{ T1 } & \multicolumn{3}{|c|}{ T2 } & \multicolumn{3}{|c|}{ T3 } & \multicolumn{3}{|c|}{ T4 } & \multicolumn{3}{|c|}{ T5 } \\
\hline $\mathrm{pH}$ & 8.83 & \pm & 0.37 & 8.87 & \pm & 0.54 & 8.82 & \pm & 0.54 & 8.78 & \pm & 0.44 & 8.78 & \pm & 0.51 \\
\hline $\mathrm{Fe}\left(\mathrm{mg} \mathrm{L}^{-1}\right)$ & 0.007 & \pm & 0.01 & 0.014 & \pm & 0.02 & 0.006 & \pm & 0.01 & 0.007 & \pm & 0.01 & 0.010 & \pm & 0.02 \\
\hline $\operatorname{Mn}\left(\mathrm{mg} \mathrm{L}^{-1}\right)$ & 0.005 & \pm & 0.01 & 0.013 & \pm & 0.02 & 0.012 & \pm & 0.02 & 0.016 & \pm & 0.03 & 0.012 & \pm & 0.02 \\
\hline $\mathrm{Cu}\left(\mathrm{mg} \mathrm{L}^{-1}\right)$ & 0.003 & \pm & 0.01 & 0.004 & \pm & 0.01 & 0.004 & \pm & 0.01 & 0.004 & \pm & 0.01 & 0.003 & \pm & 0.01 \\
\hline $\mathrm{Zn}\left(\mathrm{mg} \mathrm{L}^{-1}\right)$ & 0.003 & \pm & 0.01 & 0.009 & \pm & 0.01 & 0.006 & \pm & 0.01 & 0.015 & \pm & 0.01 & 0.006 & \pm & 0.01 \\
\hline $\mathrm{Cr}\left(\mathrm{mg} \mathrm{L}^{-1}\right)$ & 0.013 & \pm & 0.01 & 0.019 & \pm & 0.02 & 0.015 & \pm & 0.02 & 0.012 & \pm & 0.02 & 0.011 & \pm & 0.01 \\
\hline $\mathrm{Ni}\left(\mathrm{mg} \mathrm{L}^{-1}\right)$ & 0 & \pm & 0 & 0.002 & \pm & 0 & 0.002 & \pm & 0 & 0 & \pm & 0 & 0 & \pm & 0 \\
\hline $\mathrm{Cd}\left(\mathrm{mg} \mathrm{L}^{-1}\right)$ & 0.012 & \pm & 0.01 & 0.011 & \pm & 0.01 & 0.005 & \pm & 0.01 & 0.008 & \pm & 0.01 & 0.004 & \pm & 0.01 \\
\hline $\mathrm{Pb}\left(\mathrm{mg} \mathrm{L}^{-1}\right)$ & 0.120 & \pm & 0.10 & 0.080 & \pm & 0.10 & 0.015 & \pm & 0.02 & 0.088 & \pm & 0.08 & 0.055 & \pm & 0.06 \\
\hline
\end{tabular}

T1 - 100\% underground water; T2 - 75\% underground water plus 25\% treated produced water from oil TOPW; T3 - 50\% underground water plus 50\% TOPW; T4 - 25\% underground water plus $75 \%$ TOPW; and T5 - 100\% TOPW 
Forage cactus (Nopalea cochenillifera (L.) Salm-Dick) seeds of the cultivar Miúda were sown in the pots.

A localized irrigation system was used, which consisted of five 62 L PVC tanks, one for each treatment; five circulation pumps with self-ventilated electric motors (EBD250076; Metalcorte/Eberle, Caxias do Sul, Brazil); and lateral lines composed of $16-\mathrm{mm}$ polyethylene pipes with microtube emitters, which conducted the TOPW to the pots with a mean flow of $0.01 \mathrm{~m}^{3} \mathrm{~h}^{-1}$.

One forage cactus cladode was planted per pot on January 25,2018 . The cladodes were buried up to half their length, with the cut part facing the soil, which was manually compacted around the cladodes to allow a better fixation and facilitate their development. The forage cactus water demand was determined using fitting coefficients for reference evapotranspiration $\left(\mathrm{ET}_{0}\right)$ based on the Penman-Monteith equation (Allen et al., 2006). The total irrigation depth was determined using a water balance, in which the depths applied were always from the irrigation with diluted TOPW, and the water losses were from the crop evapotranspiration (ETc) and drainage. After reaching soil moisture at field capacity with underground water, all pots were irrigated only with the diluted TOPW.

The crop coefficient $(\mathrm{Kc})$ of 0.7 was used for the forage cactus at all stages, since information on irrigation for this crop in greenhouses are not found in the literature. Studies with field experiments reported Kc of 0.4 (Consoli et al., 2013), 0.52 (Queiroz et al., 2016), and 0.7 (Arba et al., 2016) for forage cactus crops.

The first irrigation applying the diluted TOPW, according to the treatments, was on February 5, 2018. The irrigations were carried out every seven days.

A total irrigation depth of $155.3 \mathrm{~mm}$ was applied to each treatment during the 240-day cycle of the forage cactus plants in the greenhouse (Table 3).

Fertilizers were not applied to prevent them to mask the data of the soil analyses at the end of the experiment; thus, the forage cactus plants received only nutrients from the diluted TOPW.

Simple soil samples were collected from the 25 experimental plots at the end of the experiment, considering the $0-0.10$ and 0.10-0.20 m layers, using a Dutch auger. The samples were stored in labeled sterile plastic bags and taken to the LASAPUFERSA to quantify iron (Fe), manganese $(\mathrm{Mn})$, copper $(\mathrm{Cu})$, zinc $(\mathrm{Zn})$, chromium $(\mathrm{Cr})$, nickel (Ni), cadmium (Cd), and lead $(\mathrm{Pb})$ contents, using an atomic absorption spectrophotometry and following standards established by Teixeira et al. (2017).

Table 3. Irrigation depths of treated produced water from oil (TOPW) and underground water (UW) applied to each treatment for soils cultivated with forage cactus over the experiment period

\begin{tabular}{cccc}
\hline \multirow{2}{*}{ Treatments } & TOPW depth & UW depth & Total depth \\
\cline { 2 - 4 } & & $(\mathbf{m m})$ & \\
T1 & 0.0 & 155.3 & 155.3 \\
T2 & 38.8 & 116.5 & 155.3 \\
T3 & 77.7 & 77.6 & 155.3 \\
T4 & 116.5 & 38.8 & 155.3 \\
T5 & 155.3 & 0.0 & 155.3 \\
\hline
\end{tabular}

T1 - 100\% underground water; T2 - 75\% underground water plus 25\% TOPW; T3 - 50\% underground water plus 50\% TOPW; T4 - 25\% underground water plus $75 \%$ TOPW; and T5 - 100\% TOPW
The statistical analyses were carried out using mean data of soils of the two layers. The data of trace elements were subjected to analysis of variance by the $\mathrm{F}$ test at $\mathrm{p} \leq 0.05$, and when significant, orthogonal contrasts were applied to compare the means, using the Sisvar 5.6 program (System for Analysis of Variance) developed by Ferreira (2014).

\section{Results AND Discussion}

Soil $\mathrm{pH}$ presented no significant changes $(\mathrm{p} \leq 0.05)$ as a function of the treatments. However, the contrast C4 was significant $(\mathrm{p} \leq 0.05)$, indicating that the $\mathrm{pH}$ of the treatment $\mathrm{T} 2$ was lower than that of the treatment $\mathrm{T} 1$. This was probably because of the higher release of $\mathrm{H}^{+}$ions by the forage cactus in $\mathrm{T} 2$ during the nutrient absorption process to balance soil charges. The mean $\mathrm{pH}$ of the soil used in the experiment (7.1-7.8) classifies it chemically as a weak alkalinity soil, and agronomically as a very high $\mathrm{pH}$ soil (>7.0) (Ribeiro et al., 1999). Moreover, the $\mathrm{pH}$ of the irrigated solution in all treatments was higher than 7.0, indicating more $\mathrm{OH}$ - than $\mathrm{H}+$ and lower risks of desorption and solubility of metals in the soil.

The orthogonal contrast $\mathrm{C} 1$ presented significant effects, indicating higher $\mathrm{Cr}$ and $\mathrm{Pb}$ contents in the treatment that received only treated produced water from oil (TOPW) (T5) than those in the other treatments (Table 4). This was probably because they were complexed to organic matter and are not essential to the forage plant species used, and because of the contribution of the solutions applied. The highest $\mathrm{Cr}$ and $\mathrm{Pb}$ contents were found in T5, which were below the limits of 75 and $72 \mathrm{mg} \mathrm{dm}^{-3}$, respectively, established by the Brazilian National Council for Environment (CONAMA; Resolution no. 420/2009; Brasil, 2009). The contents of other metals (Fe, $\mathrm{Mn}, \mathrm{Cu}, \mathrm{Zn}, \mathrm{Ni}$, and $\mathrm{Cd}$ ) showed no significant variation due to the application of diluted TOPW, probably because of the low contribution of the solutions used to supply these elements and because some of them are essential micronutrients to plant nutrition.

Figure 1 presents the $\mathrm{Fe}, \mathrm{Mn}, \mathrm{Cu}$, and $\mathrm{Zn}$ contents in the soil 0-0.10 and 0.10-0.20 m layers at the end of the experiment. Small variations were found for Fe contents between the soil layers because it is a very mobile element that is evenly distributed in the soil. Nevertheless, the highest contents were found in the 0-0.10 m layer, except for the treatment T4, which presented higher contents of this element in the deeper layer (Figure 1A).

According to the interpretation class of micronutrient availability of the Soil Fertility Commission of the State of Minas Gerais (CFSEMG) (Ribeiro et al., 1999), the mean Fe contents found in both layers of the studied soil are classified as very low ( $\leq 8 \mathrm{mg} \mathrm{dm}^{-3}$ ). The CONAMA (Resolution no. 420/2009; Brasil, 2009) presents no limit values for $\mathrm{Fe}$ contamination. The low Fe contents found can be related to high soil $\mathrm{pH}$, because the highest availability of this nutrient is found within a pH range of 4.0 to 6.0 (Novais et al., 2007).

The soil Mn contents found (Figure 1B) were higher in the deeper layer in all treatments, except for the treatment T3. The highest Mn values in the surface layer were found for T1 (underground water). Under different experimental 
Table 4. Means and orthogonal contrasts for chemical attributes of soils cultivated with forage cactus irrigated with diluted treated produced water from oil (TOPW)

\begin{tabular}{|c|c|c|c|c|c|c|c|c|c|}
\hline \multirow{3}{*}{ Treatments } & \multicolumn{9}{|c|}{ Soil chemical attributes* } \\
\hline & \multirow{2}{*}{ pH } & $\mathrm{Fe}$ & $\overline{M n}$ & Cu & $\mathbf{Z n}$ & Gr & $\mathrm{Ni}$ & Cd & $\mathbf{P b}$ \\
\hline & & \multicolumn{8}{|c|}{$\left(\mathrm{mg} \mathrm{dm^{-3 } )}\right.$} \\
\hline T1 & 7.47 & 2.43 & 0.45 & 0.002 & 0.20 & 0.017 & 0.003 & 0.0004 & 0.06 \\
\hline T2 & 7.05 & 2.45 & 0.39 & 0.002 & 0.21 & 0.019 & 0.003 & 0.0006 & 0.05 \\
\hline T3 & 7.46 & 2.50 & 0.40 & 0.002 & 0.20 & 0.020 & 0.004 & 0.0004 & 0.11 \\
\hline T4 & 7.49 & 2.62 & 0.44 & 0.002 & 0.20 & 0.018 & 0.003 & 0.0004 & 0.10 \\
\hline T5 & 7.13 & 2.55 & 0.40 & 0.001 & 0.21 & 0.029 & 0.006 & 0.0008 & 0.27 \\
\hline CONAMA $^{2}$ & - & - & - & 60 & 300 & 75 & 30 & 1.3 & 72 \\
\hline Mean & 7.32 & 2.51 & 0.42 & 0.002 & 0.20 & 0.021 & 0.004 & 0.0005 & 0.12 \\
\hline CV (\%) & 4.12 & 9.00 & 15.95 & 146.20 & 10.87 & 26.36 & 124.93 & 88.13 & 73.44 \\
\hline Standard Error & 0.13 & 0.10 & 0.03 & 0.001 & 0.01 & 0.002 & 0.002 & 0.0002 & 0.04 \\
\hline \multirow[t]{2}{*}{ Significance } & ns & $\mathrm{ns}$ & ns & ns & ns & $0.02^{\star}$ & ns & $\mathrm{ns}$ & $0.01^{* *}$ \\
\hline & \multicolumn{9}{|c|}{ Significance of contrasts } \\
\hline 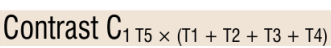 & ns & ns & ns & ns & $\mathrm{ns}$ & $0.01^{* *}$ & ns & ns & $0.01^{* *}$ \\
\hline Contrast $C_{2} T_{4} \times\left(T 1+T 2+T_{3}\right)$ & ns & ns & ns & ns & ns & ns & ns & ns & ns \\
\hline Contrast $\mathrm{C}_{3 \top 3 \times\left(T 1+T_{2}\right)}$ & ns & ns & ns & ns & ns & ns & ns & ns & ns \\
\hline Contrast $\mathrm{C}_{4 \mathrm{~T} 2 \times \mathrm{T} 1}$ & $0.04^{*}$ & ns & ns & ns & ns & $\mathrm{ns}$ & ns & $\mathrm{ns}$ & $\mathrm{nS}$ \\
\hline
\end{tabular}

${ }^{1}$ Mean values from samples of the 0-0.10 and 0.10-0.20 m soil layers; ${ }^{2}$ CONAMA - CONAMA Resolution no. 420/2009; Brasil, 2009; T1 - 100\% underground water; T2 - 75\% underground water plus 25\% TOPW; T3 - 50\% underground water plus 50\% TOPW; T4 - 25\% underground water plus 75\% TOPW; and T5 - 100\% TOPW; ns - not significant

A.
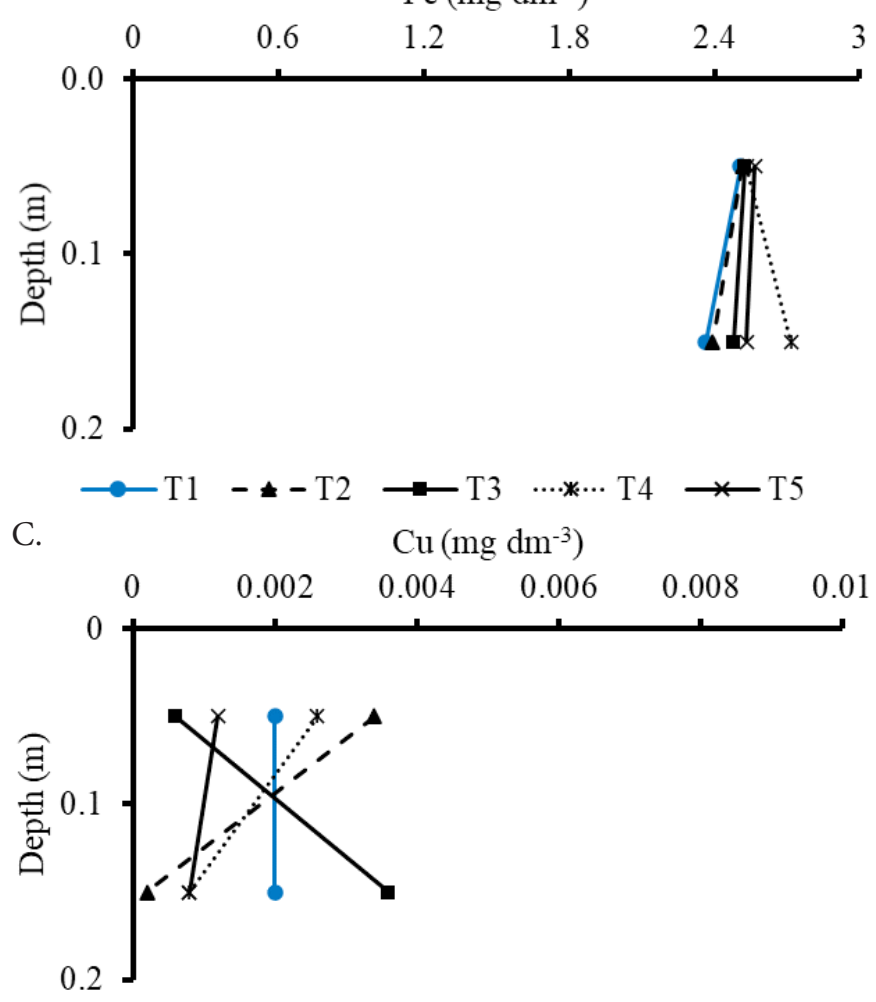

$\longrightarrow \mathrm{T} 1 \quad \rightleftarrows-\mathrm{T} 2 \longrightarrow \mathrm{T} 3 \quad \cdots * \cdots \mathrm{T} 4 \quad * \mathrm{~T} 5$
B.

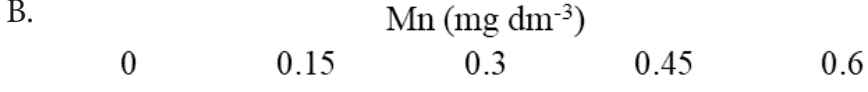

T1 - 100\% underground water; T2 - 75\% underground water plus 25\% TOPW; T3 - 50\% underground water plus 50\% TOPW; T4 - 25\% underground water plus 75\% TOPW; and T5 - 100\% TOPW

Figure 1. Distribution of Fe (A), Mn (B), Cu (C), and $\mathrm{Zn}(\mathrm{D})$ contents in the 0-0.10 and 0.10-0.20 m layers of soils cultivated with forage cactus irrigated with diluted treated oil produced water (TOPW)

conditions, Weber et al. (2017) evaluated three production cycles of sunflower irrigated with produced water and found decreases in Mn contents throughout the soil profile, regardless of the treatment used, and with underground water (control).

Based on Ribeiro et al. (1999), the mean Mn contents found are classified as very low $\left(\leq 2 \mathrm{mg} \mathrm{dm}^{-3}\right)$ for the two evaluated soil layers. The CONAMA (Resolution no. 420/2009; Brasil, 2009) presents no limit values for prevention of soil contamination by $\mathrm{Mn}$.
Figure $1 \mathrm{C}$ shows that the $\mathrm{Cu}$ contents were lower in the 0.10-0.20 m layer, except for T1, which had similar contents in both layers, and T3, which presented higher Mn contents in 0.10-0.20 $\mathrm{m}$ layer.

From the environmental point of view, $\mathrm{Cu}$ contents in both layers were below the limit of $60 \mathrm{mg} \mathrm{dm}^{-3}$ (dry weight) established by the CONAMA (Resolution no. 420/2009; Brasil, 2009) for prevention of soil contamination by residues and effluents. 
Preston et al. (2014) established reference values for soil quality regarding heavy metals for soils of the state of Rio Grande do Norte, Brazil. Based on these reference values, the mean $\mathrm{Cu}$ contents found in both evaluated soil layers were below the maximum limit of $13.69 \mathrm{mg} \mathrm{dm}^{-3}$.

The $\mathrm{Zn}$ contents were higher in the deeper layer for T1, T2, and T4, and higher in the surface layer for T3 and T5 (Figure 1D). The $\mathrm{Zn}$ contents were classified as very low $\left(\leq 0.4 \mathrm{mg} \mathrm{dm}^{-3}\right)$ for both soil layers, according to Ribeiro et al. (1999). The mean soil $\mathrm{Zn}$ contents were below the reference value (23.85 $\mathrm{mg} \mathrm{dm}^{-3}$ ) established by Preston et al. (2014); and below the limit ( $300 \mathrm{mg} \mathrm{dm}^{-3}$ ) established by the CONAMA (Resolution no. 420/2009; Brasil, 2009).

Soils from basic igneous rocks are richer, and those from sedimentary arenite rocks are poorer in $\mathrm{Zn}$ contents (Novais et al., 2007). The low $\mathrm{Zn}$ contents found can be explained by the soil used in the experiment, which was from an area with geological predominance of limestones from the Jandaíra formations, which encompass calcarenite and bioclastic calcilutite, and arenites from the Açu formations (Angelim et al., 2006).

According to Novais et al. (2007), the highest $\mathrm{Mn}, \mathrm{Cu}$, and $\mathrm{Zn}$ availabilities are found under a $\mathrm{pH}$ range of 5.0 to 6.5; however, the soil used in the experiment presented $\mathrm{pH}$ above this range, thus expressing low values for these elements.

Cr contents were practically unchanged in both soil layers (0-0.10 and 0.10-0.20) in all treatments; T5 presented the highest values in both layers (Figure 2A).

According to the CONAMA (Resolution no. 420/2009; Brasil, 2009), the mean Cr contents found in both layers were

A.
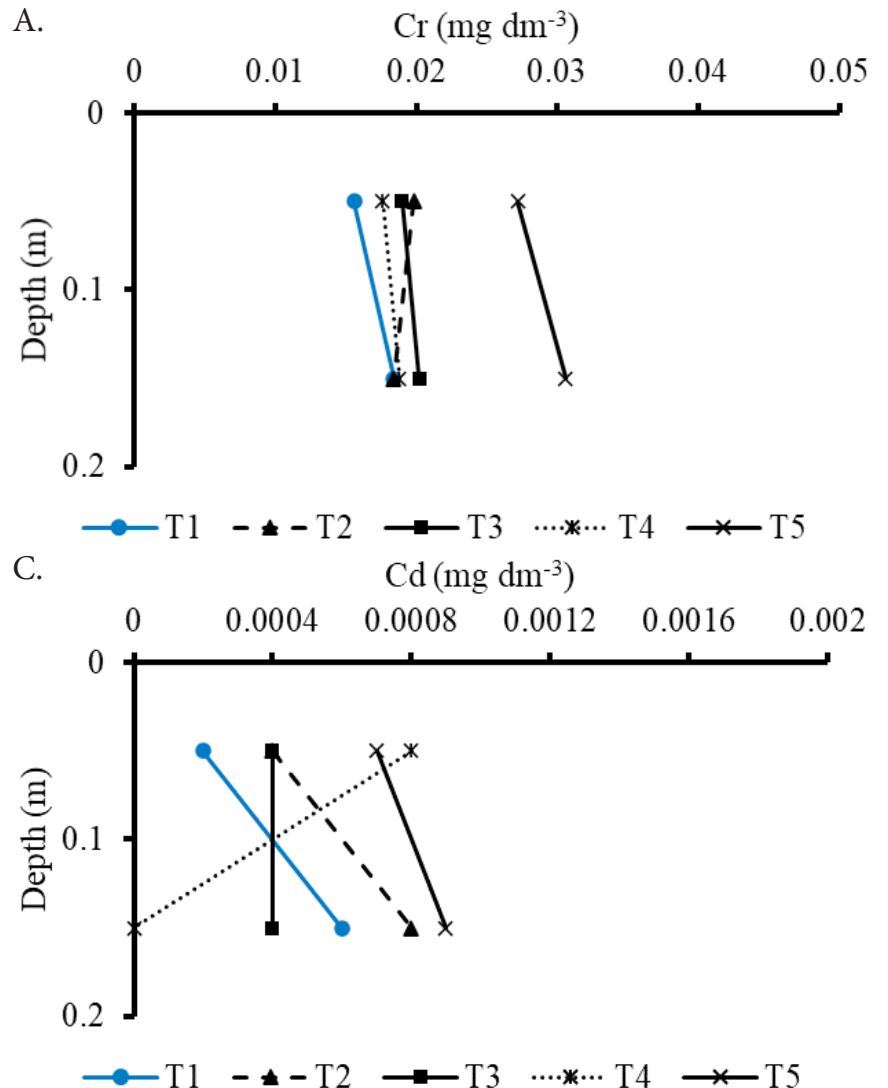

T3 …*.. T4

$\mathrm{T} 5$

T1 - 100\% underground water; T2 - 75\% underground water plus 25\% TOPW; T3 - 50\% underground water plus 50\% TOPW; T4 - 25\% underground water plus $75 \%$ TOPW; and T5 - 100\% TOPW

Figure 2. Distribution of $\mathrm{Cr}(\mathrm{A}), \mathrm{Ni}(\mathrm{B}), \mathrm{Cd}(\mathrm{C})$, and $\mathrm{Pb}(\mathrm{D})$ contents in the $0-0.10$ and $0.10-0.20 \mathrm{~m}$ layers of soils cultivated with forage cactus irrigated with diluted treated produced water from oil (TOPW)

below the limit considered for prevention of toxicity $\left(75 \mathrm{mg} \mathrm{dm}^{-3}\right)$. Considering the reference values established by Preston et al. (2014), Cr contents were also below the limit of $30.94 \mathrm{mg} \mathrm{dm}^{-3}$.

The highest Ni contents were found for T5 (only TOPW) in both soil layers, and the lowest was found for T1 (only underground water) in the soil surface layer (Figure 2B). Costa (2018) found different results, with higher Ni contents in the soil surface layer when irrigated only with underground water (control). The mean Ni contents in both layers were below the limit of $30 \mathrm{mg} \mathrm{dm}^{-3}$, which was established by the CONAMA (Resolution no. 420/2009; Brasil, 2009) for prevention of toxicity; and also below the reference values for Ni contents (19.84 mg $\mathrm{dm}^{-3}$ ) in soils of Rio Grande do Norte (Preston et al., 2014).

$\mathrm{Cd}$ contents were higher in the deeper soil layer for T1, T2, and T5; and lower for T4. Only T3 had similar Cd contents in both layers (Figure 2C). According to Cunha et al. (2008), Cd is highly mobile in the soil and is found mainly at the exchangeable stage. According to the limits established by the CONAMA (Resolution no. 420/2009; Brasil, 2009), the Cd contents found in both soil layers were below the limit $\left(1.3 \mathrm{mg} \mathrm{dm}^{-3}\right)$ considered for prevention of toxicity. The $\mathrm{Cd}$ contents found were also below the reference value $\left(0.1 \mathrm{mg} \mathrm{dm}^{-3}\right)$ established for soils of the Rio Grande do Norte (Preston et al., 2014).

The lower $\mathrm{Pb}$ contents were found for $\mathrm{T} 2$ in both soil layers. $\mathrm{T} 1$ and $\mathrm{T} 3 \mathrm{had}$ practically similar Pb contents in both layers, whereas T4 had higher contents in the deeper layer, and T5 had higher contents in the surface layer (Figure 2D). According to the CONAMA (Resolution no. 420/2009; Brasil, 2009), the $\mathrm{Pb}$ contents found in both layers were below the limit of

B.
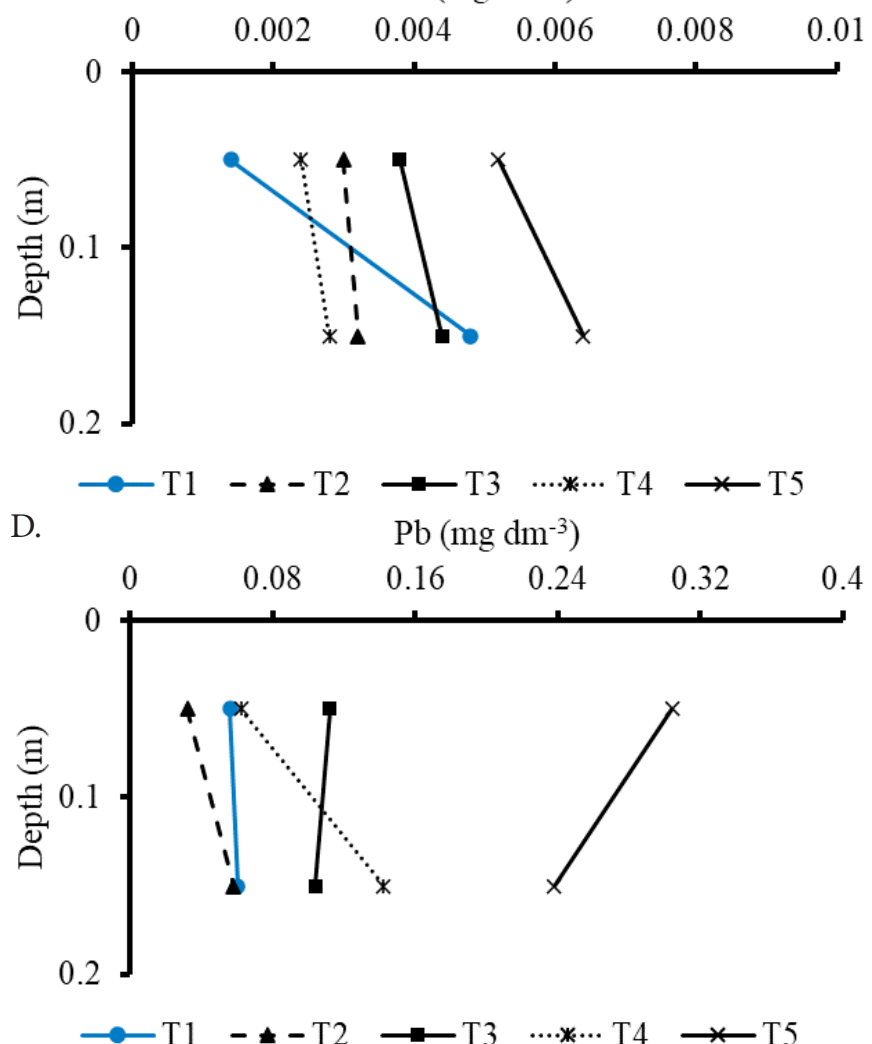

$\longrightarrow \mathrm{T} 1 \quad \ldots-\mathrm{T} 2 \rightarrow \mathrm{T} 3 \quad \cdots * \cdots \mathrm{T} 4 \underset{\mathrm{T}}{\longrightarrow}$ 
$72 \mathrm{mg} \mathrm{dm}^{-3}$, which was established for prevention of toxicity. The $\mathrm{Pb}$ contents found were also below the reference value (16.18 $\mathrm{mg} \mathrm{dm}^{-3}$ ) established by Preston et al. (2014) for soils of Rio Grande do Norte. Lima \& Meurer (2013) reported that $\mathrm{Pb}$ has high probability of accumulation in organic matter, and its absorption by the plant depends on its content and form in the soil. However, PB is a metal that can be absorbed at low and high concentrations, despite of being little mobile in the soil.

\section{Conclusions}

1. The use of irrigations with diluted treated produced water from oil does not cause contamination of soils cultivated with forage cactus (Nopalea cochenillifera) by $\mathrm{Fe}, \mathrm{Mn}, \mathrm{Cu}, \mathrm{Zn}, \mathrm{Cr}$, $\mathrm{Ni}, \mathrm{Cd}$, and $\mathrm{Pb}$.

2. The $\mathrm{Cr}$ and $\mathrm{Pb}$ contents in soils cultivated with forage cactus irrigated with $100 \%$ treated produced water from oil were significantly higher than those in soils irrigated with $100 \%$ underground water.

\section{Literature Cited}

Al-Ghouti, M. A.; Al-Kaabi, M. A.; Ashfaq, M. Y.; Da’na; D. A. Produced water characteristics, treatment and reuse: A review. Journal of Water Process Engineering, v.28, p.222-239, 2019. https://doi.org/10.1016/j.jwpe.2019.02.001

Allen, R. G.; Pereira, L. S.; Raes, D; Smith, M. Evapotranspiración del cultivo, Guías para la determinación de los requerimientos de água de los cultivos. Roma: FAO, 2006. 298p.

Álvares, C. A.; Stape, J. L.; Sentelhas, P. C.; Gonçalves, J. L. de M.; Sparovek, G. Köppen's climate classification map for Brazil. Meteorologische Zeitschrift, v.22, p.711-728, 2013. https://doi. org/10.1127/0941-2948/2013/0507

Angelim, L. A. A.; Angelim, V. C.; Nesi, J. R. Programa Geologia do Brasil - PLGB. Projeto Geologia e Recursos Minerais do Estado do Rio Grande do Norte. Mapa geológico do Estado do Rio Grande do Norte. Escala 1:500.000. Recife: CPRM/FAPERN, 2006.

Arba, M.; Falisse, A.; Choukr-Allah, R.; Sindic, M. Effects of irrigation at critical crop stages on fruit yield and quality of cactus pear (Opuntia spp.). Scientific Journal of Crop Science, v.5, p.73-81, 2016.

Brasil. Conselho Nacional de Meio Ambiente. Resolução No 420 de 28 de dezembro de 2009. Dispõe sobre critérios e valores orientadores de qualidade do solo quanto à presença de substâncias químicas e estabelece diretrizes para o gerenciamento ambiental de áreas contaminadas por essas substâncias em decorrência de atividades antrópicas. Brasília: Diário Oficial da República Federativa do Brasil, 2009, p.81-84.

BP - British Petroleum. Energy Outlook 2017 Edition: Data Tables. [WWWDocument]. Available on: <https://www.bp.com/en/ global/corporate/energy-economics/energy-outlook/energyoutlook-downloads.html>. Accessed on: Dez. 2019.

Consoli, S.; Inglese, G.; Inglese, P. Determination of Evapotranspiration and annual biomass productivity of a cactus pear [Opuntia ficus indica L. (Mill.)] orchard in a semiarid environment. Journal of Irrigation and Drainage Engineering. v.139, p.680-890, 2013. https://doi.org/10.1061/(ASCE)IR.19434774.0000589
Costa, F. G. B. Produção e capacidade de fitoextração do girassol (Heliantus annus) irrigado com água produzida. Mossoró: UFERSA, 2018. 92p. Tese Doutorado

Costa, F. G. B.; Batista, R. O.; Pereira, J. O.; Ferreira Neto, M.; Alves, S. M. C.; Simões, W. L.; Souza, L.; Pordeus, R. V. Productive and morphogenetic characteristics of sunflower irrigated with domestic treated wastewater on northeast semiarid area. Australian Journal of Crop Science, v.12, p.1184-1190, 2018. https://doi.org/10.21475/ajcs.18.12.07.PNE1158

Cunha, K. P. V. da; Nascimento, C. W. A. do; Pimentel, R. M. de M.; Accioly, M. de A.; Silva, A. J. da. Disponibilidade, acúmulo e toxidez de cádmio e zinco em milho cultivado em solo contaminado. Revista Brasileira de Ciência do Solo, v.32, p.1319-1328, 2008. https://doi.org/10.1590/S010006832008000300039

Drioli, E.; Ali, A.; Lee, Y. M.; Al-Sharif, S. F.; Al-Beirute, M.; Macedonio, F. Membrane operations for produced water treatment. Desalination and Water Treatment, v.57, p. 1431714335, 2016. https://doi.org/10.1080/19443994.2015.1072585

Echchelh, A.; Hess, T.; Sakrabani, R.; Paz, J. M.; Visconti, F. Assessing the environmental sustainability of irrigation with oil and gas produced water in drylands. Agricultural Water Management, v.223, p.1-12, 2019. https://doi.org/10.1016/j. agwat.2019.105694

Ferreira, D. F. Sisvar: A Guide for its bootstrap procedures in multiple comparisons. Ciência e Agrotecnologia, v.38, p.109-112, 2014. https://doi.org/10.1590/S1413-70542014000200001

Ferreira, R. N. C.; Weber, O. B.; Crisóstomo, L. A. Produced water irrigation changes the soil mesofauna community in a semiarid agroecosystem. Environmental Monitoring and Assessment, v.187, p.1-9, 2015. https://doi.org/10.1007/s10661-015-4744-7

Lima, C. V. S. de; Meurer, E. J. Elementos-traço no solo, nas águas e nas plantas de uma lavoura de arroz irrigado do Rio Grande do Sul. Revista de Estudos Ambientais, v.15, p.20-30, 2013.

Novais, R. F.; Alvarez V., V. H.; Barros, N. F.; Fontes, R. L. F.; Cantarutti, R. B.; Neves, J. C. L. Fertilidade do solo. Viçosa: SBCS, 2007. 1017p.

Pica, N. E.; Carlson, K.; Steiner, J. J.; Waskom, R. Produced water reuse for irrigation of non-food biofuel crops: Effects on switchgrass and rapeseed germination, physiology and biomass yield. Industrial Crops and Products, v.100, p.65-76, 2017. https://doi.org/10.1016/j.indcrop.2017.02.011

Preston, W.; Nascimento, C. W. A. do; Biondi, C. M.; Souza Junior, V. S. de; Silva, W. R. da; Ferreira, H. A. Valores de referência de qualidade para metais pesados em solos do Rio Grande do Norte. Revista Brasileira de Ciência do Solo, v.38, p.1028-1037, 2014. https://doi.org/10.1590/S0100-06832014000300035

Queiroz, M. G.; Silva, T. G. R.; Zolnier, S.; Silva, S. M. S; Souza, C. A. A.; Carvalho, H. F. S. Relações hídrico-econômicas da palma forrageira cultivada em ambiente semiárido. Irriga, v.1, p.141154, 2016. https://doi.org/10.15809/irriga.2016v1n01p141-154

Ribeiro, A. C.; Guimarães, P. T. G.; Alvarez V., V. H. (eds.). Recomendações para o uso de corretivos e fertilizantes em Minas Gerais: $5^{\text {a }}$ aproximação. Viçosa: Comissão de Fertilidade do Solo do Estado de Minas Gerais, 1999. 359p.

Rice, E. W.; Baird, R. B.; Clesceri, A. D. Standard methods for the examination of water and wastewater. 22. ed. Washington: APHA, 2012. 1496p. 
Santos, E. V.; Bezerra Rocha, J. H.; Araújo, D. M.; Moura, D. C.; Martínez-Huitle, C. A. Decontamination of produced water containing pretoleum hydrocarbons by electrochemical methods: A minireview. Environmental Science and Pollution Research. v.21, p.8432-8441, 2014. https://doi.org/10.1007/s11356-014-2780-4

Sousa, A. F.; Crisóstomo, L. A.; Weber, O. B.; Escobar, M. E. O.; Oliveira, T. S. Nutrient content in sunflowers irrigated with oil exploration water. Revista Caatinga, v.29, p.94-100, 2016. https://doi.org/10.1590/1983-21252016v29n111rc
Teixeira, P. C.; Donagemma, G. K.; Wenceslau, A. F.; Teixeira, G. Manual de métodos de análise de solo. 3.ed. Rio de Janeiro: Embrapa Solos, 2017. 573p.

Weber, O. B.; Crisóstomo, L. A.; Miranda, F. R. de; Sousa, A. F.; Mesquita, A. L. M.; Cabral, J. E. de O. Production of ornamental sunflower irrigated with oilfield produced water in the Brazilian semiarid region. Pesquisa Agropecuária Brasileira, v.52, p.443-454, 2017. https://doi.org/10.1590/ s0100-204x2017000600008 